\title{
Analisis Dissolved Gas Analysis Dan Klasifikasi Tipe Fault Pada Minyak Trafo Dengan Metode Naive Bayes Classifier Pada Transformator Daya $150 \mathrm{kV}$
}

\author{
Sofia Ariyani ${ }^{1}$ \\ ${ }^{1}$ Jurusan Teknik Elektro, Universitas Muhammadiyah Jember , Indonesia
}

ABSTRACT (10 PT)

\begin{abstract}
Transformers are very important in electric power systems as well as in industry, therefore preventive maintenance is very necessary. One such treatment is the treatment of transformer oil. DGA (is an analysis of dissolved gas in transformer insulation oil and is one form of treatment for transformer insulation oil). In this final project, we will discuss how to analyze transformer oil data from DGA test and fault type classification using the naive bayes classifier method. The data from the transformer oil test with the DGA will later be classified which are then analyzed using Naive Bayes classifier and calculate the evaluation results with precision, recall, accuracy.
\end{abstract}

Keyword : Power systems, DGA

\begin{abstract}
ABSTRAK (10 PT)
Trafo sangat penting dalam sistem tenaga listrik maupun pada industri, oleh karena itu perawatan preventif sangat diperlukan. Salah satu perawatan tersebut adalah perawatan dari minyak trafo. DGA (merupakan analisis gas terlarut pada minyak isolasi transformator dan merupakan salah satu bentuk perawatan untuk minyak isolasi transformator). Dalam tugas akhir ini akan membahas bagaimana menganalisa data minyak trafo hasil uji DGA dan klasifikasi tipe fault menggunakan metode naive bayes classifier. Data hasil uji minyak trafo dengan DGA nantinya akan diklasifikasikan yang selanjutnya dianalisis menggunakan naive bayes classifier dan menghitung hasil evaluasi dengan pencarian presisi, recall, akurasi.
\end{abstract}

Kata kunci : DGA, minyak trafo, fault, naive bayes

\section{PENDAHULUAN}

Salah satu penyebab utama munculnya kegagalan pada transformator adalah adanya panas yang berlebih. Panas yang berlebih akan memacu reaksi berantai yang akan mempercepat penurunan usia dan kualitas kerja sistem isolasi. Untuk pemeliharaan pada minyak isolasi pengujian dilakukan dengan metode DGA (Dissolved Gas Analysis). DGA merupakan metode pengujian yang dilakukan untuk menguji keadaan minyak isolasi dengan mengambil sampel minyak isolasi dari unit transformator untuk mengetahui jenisjenis gas yang terlarut dalam minyak isolasi transformator, dari hasil tes DGA tersebut akan dapat disimpulkan dan diprediksikan jenis gangguan yang mungkin terjadi pada transformator dan dapat segera dilakukan tindakan pencegahan kegagalan transformator. Hal ini mendukung diperlukannya suatu proses klasifikasi terhadap dokumen dokumen. Klasifikasi adalah proses untuk menemukan model atau fungsi yang menjelaskan atau membedakan konsep atau kelas data, dengan tujuan untuk dapat memperkirakan kelas dari suatu objek (Agus Mulyanto 2009). Klasifikasi merupakan proses awal dari pengelompokkan data. Proses klasifikasi dokumen merupakan proses yang sangat penting dalam bidang sistem informasi, khususnya dalam proses penambangan data (data mining) untuk memperoleh pengetahuan bisnis (business knowledge). Saya akan membahas "Analisis Dissolved Gas Analysis dan Klasifikasi Tipe Fault pada Minyak Trafo dengan Metode Naive Bayes Classifier pada Transformator Daya $150 \mathrm{kV}$ ".

\section{KAJIAN PUSTAKA DAN PENGEMBANGAN HIPOTESIS}

Transformator merupakan peralatan listrik yang berfungsi untuk menyalurkan daya/tenaga dari tegangan tinggi ke tegangan rendah atau sebaliknya. Transformator memiliki beberapa komponen penting untuk dapat beroperasi, antara lain sebagai berikut; Electromagnetic Circuiz (Inti Besi), Kumparan Transformator, Minyak, Bushing, Tangki Konservator, Pendingin, Alat Pernapasan (Silicagel), Indikator, 
Rele. Metode Pengujian DGA (Dissolved Gas Analysis). Definisi DGA merupakan analisa kondisi transformator yang dilakukan berdasarkan jumlah gas terlarut pada minyak trafo.

Keuntungan Uji DGA : Deteksi dini akan adanya fenomena kegagalan yang ada pada transformator yang diujikan.

Kelemahan Uji DGA : Diperlukan tingkat kemurnian yang tinggi dari sampel minyak yang diujikan. Metode Interpretasi data uji DGA yang tercantum pada IEEE (TDCG), yaitu :

1) Standar IEEE (TDCG), Key Gas, Roger Ratio, Duval's Triangle.

Naïve Bayes Classifier merupakan sebuah metoda klasifikasi yang berakar pada teorema Bayes. Ciri utama dari Naïve Bayes Classifier ini adalah asumsi yang sangat kuat (naif) akan independensi dari masing-masing kondisi/kejadian. Pada teorema Bayes, bila terdapat dua kejadian yang terpisah (misalkan A dan B), maka teorema Bayes dirumuskan sebagai berikut:

$\mathrm{P}(\mathrm{A} \mid \mathrm{B})=(\mathrm{P}(\mathrm{A})) /(\mathrm{P}(\mathrm{B})) \mathrm{P}(\mathrm{B} \mid \mathrm{A})$

Teorema Bayes sering pula dikembangkan mengingat berlakunya hukum probabilitas total, menjadi seperti berikut:

$P(A \mid B)=\frac{P(A) P(B \mid A)}{\sum_{i=1}^{n} P(A i \mid B)}$ dimana A1U A2 U ... U An $=\mathrm{S}$

Untuk menjelaskan teorema Nä̈ve Bayes, perlu diketahui bahwa proses klasifikasi memerlukan sejumlah petunjuk untuk menentukan kelas apa yang cocok bagi sampel yang dianalisis tersebut. Karena itu, teorema Bayes di atas disesuaikan sebagai berikut:

$P\left(C \mid F_{1} \ldots F \mathrm{n}\right)=\frac{P(C) P(F 1 \ldots F n \mid C)}{P(F 1 \ldots F n)}$

Dimana variabel C merepresentasikan kelas, sementara variabel F1 ... Fn merepresentasikan karakteristikkarakteristik petunjuk yang dibutuhkan untuk melakukan klasifikasi. Maka rumus tersebut menjelaskan bahwa peluang masuknya sampel dengan karakteristik tertentu dalam kelas C (posterior) adalah peluang munculnya kelas $\mathrm{C}$ (sebelum masuknya sampel tersebut, seringkali disebut prior), dikali dengan peluang kemunculan karakteristikkarakteristik sampel pada kelas $\mathrm{C}$ (disebut juga likelihood), dibagi dengan peluang kemunculan karakteristik-karakteristik sampel secara global (disebut juga evidence). Karena itu, rumus (3) dapat pula ditulis secara sederhana sebagai berikut:

Posterior $=\frac{\text { prior } x \text { likelihood }}{\text { evidence }}$

Nilai evidence selalu tetap untuk setiap kelas pada satu sampel. Nilai dari Posterior tersebut yang nantinya akan dibandingkan dengan nilai-nilai Posterior kelas lainnya untuk menentukan ke kelas apa suatu sampel akan diklasifikasikan.

\section{METODE PENELITIAN}

Tahapan penyusunan Penelitian ini yaitu dengan cara sebagai berikut; Studi Literatur, Pengambilan Data, Pengolahan Data, Penyelesaian Laporan. Pengumpulan data Dissolved Gas Analysis (DGA). Langkah yang dilakukan untuk melakukan pengujian DGA:

1. Pengambilan sampel uji minyak isolasi yang ada pada transformator.

2. Ekstraksi gas dengan menggunakan peralatan DGA itu sendiri.

3. Interpretasi data, memperoleh hasil data dari uji sampel minyak isolasi yang dilakukan.

4. Analisis data tersebut dengan menggunakan Naive Bayes Classifier

5. Pengambilan kesimpulan, setelah mendapatkan hasil data gas yang telah dianalisis dengan menggunakan Naive Bayes Classifier untuk menentukan keadaan minyak transformator tersebut. Setelah didapat data keluaran berupa jenis gas pada minyak isolasi barulah kita analisis menggunakan Naive Bayes Classifier.

Data-data yang sudah terkumpul tersebut selanjutnya diolah melalui perhitungan dan analisis menggunakan naive bayes classifier. Dalam menggunakan metode naive bayes kita perlu menghitung mean/rata-rata, standart deviasi, fungsi probabilitas. Untuk mempermudah perhitungan penulis menggunakan microsoft excel. Dalam microsot excel rumus yang digunakan untuk metode naive bayes classifier sebagai berikut: 
mean (=AVERAGE(NumberX:NumberX));

standart deviasi (=STDEV(numberX:numberX);

probabilitas (=NORMDIST(x;Mean;StandartDeviasi;Commulative)).

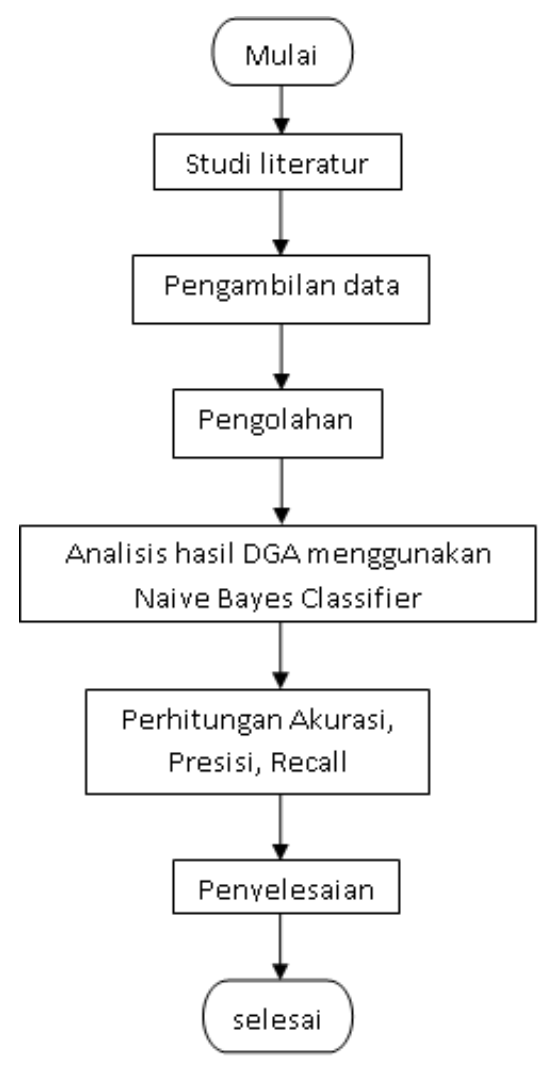

Gambar 3.1 Diagram Blok Sistem Kerja Alat

Tahapan perhitungan dan analisis menggunakan naive bayes classifier:

- Mengklasifikasikan data hasil uji minyak transformator

- Mengklasifikasikan dataset untuk training

- Mengklasifikasikan dataset untuk testing

- Pehitungan Probability dataset testing dalam domain K1

- Pehitungan Probability dataset testing dalam domain K2

- Pehitungan Probability dataset testing dalam domain K3

- Pehitungan Probability dataset testing dalam domain K4

- Nilai posterior dataset testing dan penentuan kelas.

- Analisis data sesuai nilai posterior pada kelas-kelas tertentu.

Akurasi, Presisi, Recall

Dalam "dunia" pengenalan pola (pattern recognition) dan temu kembali informasi (information retrieval), precision dan recall adalah dua perhitungan yang banyak digunakan untuk mengukur kinerja dari sistem / metode yang digunakan. Precision adalah tingkat ketepatan antara informasi yang diminta oleh pengguna dengan jawaban yang diberikan oleh sistem. Sedangkan recall adalah tingkat keberhasilan sistem dalam menemukan kembali sebuah informasi. Accuracy didefinisikan sebagai tingkat kedekatan antara nilai prediksi dengan nilai aktual.

\section{HASIL DAN PEMBAHASAN}

Pengklasifikasian menggunakan naive bayes classifier terdapat 4 kondisi yaitu; kondisi 1, kondisi 2, kondisi 3 , kondisi 4. 
Tabel 4.1 Kondisi Minyak Trafo

\begin{tabular}{cc}
\hline K1 & $\begin{array}{c}\text { TDCG pada kondisi ini mengindikasikan } \\
\text { bahwa operasi trafo normal }\end{array}$ \\
\hline K2 & $\begin{array}{c}\text { TDCG kondisi ini menandakan } \\
\text { komposisi gas melebihi batas normal } \\
\text { harus diinvestigasi secara cepat }\end{array}$ \\
& $\begin{array}{c}\text { TDCG level ini mengindikasikan } \\
\text { pemburukan tingkat tinggi, harus } \\
\text { diinvestigasi dengan cepat. }\end{array}$ \\
\hline K3 & $\begin{array}{c}\text { TDCG pada level ini mengindikasikan } \\
\text { pemburukan sangat tinggi. Yang } \\
\text { mengarah pada kerusakan trafo. }\end{array}$
\end{tabular}

Dua Tahapan Klasifikasi yaitu;

Learning (training): Pembelajaran menggunakan data training (untuk Naïve Bayesian Classifier, nilai probabilitas dihitung dalam proses pembelajaran).

Testing: Menguji model menggunakan data testing.

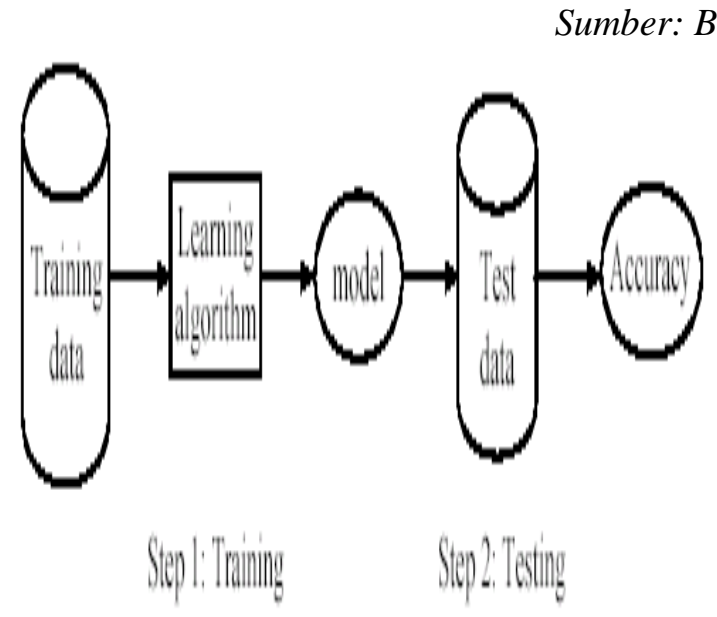

Gambar 4.1 Dua Tahapan Klasifikasi

Untuk tahap pengklasifikasian, data yang akan dianalisis menggunakan naive bayes membutuhkan banyak data. Kami membatasi banyaknya data karena data hasil uji minyak trafo dengan DGA yang menghasilkan kondisi 4 sangat sulit.

Tabel 4.2 Data Set DGA

\begin{tabular}{|c|c|c|c|c|c|c|c|}
\hline $\begin{array}{l}\mathrm{N} \\
\mathrm{o}\end{array}$ & $\begin{array}{l}\text { Tgl } \\
\text { Uji }\end{array}$ & $\begin{array}{l}\text { Hydr } \\
\text { ogen } \\
\text { (H2) }\end{array}$ & $\begin{array}{l}\text { Metane } \\
\text { (CH4) }\end{array}$ & $\begin{array}{l}\text { Ethane } \\
\text { (C2H6) }\end{array}$ & $\begin{array}{l}\text { Ethyle } \\
\text { ne } \\
(\mathrm{C} 2 \mathrm{H} 4)\end{array}$ & $\begin{array}{l}\text { TD } \\
\text { CG }\end{array}$ & $\begin{array}{l}\text { Kon } \\
\text { disi }\end{array}$ \\
\hline 1 & $\begin{array}{c}19- \\
\text { Mar } \\
-09 \\
\end{array}$ & $\begin{array}{c}243, \\
14\end{array}$ & 14,32 & 18,44 & 0,00 & $\begin{array}{r}275 \\
, 90\end{array}$ & \multirow{4}{*}{ K1 } \\
\hline 2 & $\begin{array}{c}16- \\
\text { Jun- } \\
09\end{array}$ & $\begin{array}{c}647, \\
95\end{array}$ & 27,49 & 23,48 & 1,77 & $\begin{array}{l}702 \\
, 21\end{array}$ & \\
\hline 3 & $\begin{array}{c}- \\
\text { Mar } \\
-11\end{array}$ & $\begin{array}{c}448, \\
79\end{array}$ & 36,55 & 29,43 & 45,83 & $\begin{array}{r}564 \\
, 07\end{array}$ & \\
\hline 4 & $\begin{array}{l}17- \\
\text { Nov }\end{array}$ & $\begin{array}{c}137, \\
50\end{array}$ & 120,68 & 49,32 & 0,00 & $\begin{array}{r}307 \\
50\end{array}$ & \\
\hline
\end{tabular}




\begin{tabular}{|c|c|c|c|c|c|c|c|}
\hline 5 & $\begin{array}{c}22- \\
\text { Dec- } \\
08\end{array}$ & $\begin{array}{r}145 \\
7,48\end{array}$ & 103,45 & 50,91 & 0,98 & $\begin{array}{c}161 \\
2,8 \\
2 \\
\end{array}$ & \multirow{4}{*}{$\mathrm{K} 2$} \\
\hline 6 & $\begin{array}{c}\text { 6- } \\
\text { Apr- } \\
09\end{array}$ & $\begin{array}{c}689 \\
61\end{array}$ & 38,74 & 46,59 & 0,00 & $\begin{array}{c}825 \\
, 21\end{array}$ & \\
\hline 7 & $\begin{array}{c}13- \\
\text { Oct- } \\
09\end{array}$ & $\begin{array}{r}153 \\
4,56\end{array}$ & 79,04 & 40,63 & 0,00 & $\begin{array}{c}165 \\
4,2 \\
3\end{array}$ & \\
\hline 8 & $\begin{array}{c}15- \\
\text { Feb- } \\
10\end{array}$ & $\begin{array}{r}153 \\
7,78\end{array}$ & 96,65 & 67,10 & 1,07 & $\begin{array}{c}170 \\
2,6 \\
0 \\
\end{array}$ & \\
\hline 9 & $\begin{array}{c}30- \\
\text { Jan- } \\
09\end{array}$ & $\begin{array}{l}235 \\
6,65\end{array}$ & 119,52 & 63,42 & 1,79 & $\begin{array}{c}254 \\
1,3 \\
8\end{array}$ & \multirow{4}{*}{$\mathrm{K} 3$} \\
\hline 10 & $\begin{array}{c}25- \\
\text { Jan- } \\
10\end{array}$ & $\begin{array}{c}276 \\
9,87\end{array}$ & 117,71 & 84,58 & 1,04 & $\begin{array}{c}297 \\
3,2 \\
0\end{array}$ & \\
\hline 11 & $\begin{array}{c}21- \\
\text { Sep- } \\
10\end{array}$ & $\begin{array}{l}280 \\
9,77\end{array}$ & 188,66 & $\begin{array}{c}110,5 \\
6\end{array}$ & 1,47 & $\begin{array}{c}311 \\
4,0 \\
6\end{array}$ & \\
\hline 12 & $\begin{array}{c}\text { 6- } \\
\text { Oct- } \\
11 \\
\end{array}$ & $\begin{array}{l}209 \\
2,38\end{array}$ & 84,87 & $\begin{array}{c}111,9 \\
0\end{array}$ & 0,96 & $\begin{array}{c}229 \\
0,1 \\
1\end{array}$ & \\
\hline 13 & $\begin{array}{c}15- \\
\text { Jan- } \\
08\end{array}$ & $\begin{array}{l}489 \\
3,09\end{array}$ & 388,44 & $\begin{array}{c}236,5 \\
9\end{array}$ & 0,00 & $\begin{array}{c}551 \\
8,1 \\
2\end{array}$ & \multirow{4}{*}{$\mathrm{K} 4$} \\
\hline 14 & $\begin{array}{c}26- \\
\text { Feb- } \\
08\end{array}$ & $\begin{array}{c}748 \\
0,23\end{array}$ & 489,55 & $\begin{array}{c}221,7 \\
6\end{array}$ & 11,60 & $\begin{array}{c}802 \\
3,1 \\
4\end{array}$ & \\
\hline 15 & $\begin{array}{c}18- \\
\text { Jun- } \\
08\end{array}$ & $\begin{array}{c}535 \\
0,58\end{array}$ & 510,66 & $\begin{array}{c}444,9 \\
2\end{array}$ & 2,84 & $\begin{array}{c}633 \\
0,2 \\
7\end{array}$ & \\
\hline 16 & $\begin{array}{c}1- \\
\text { Feb- } \\
11\end{array}$ & $\begin{array}{l}550 \\
5,06\end{array}$ & 287,91 & $\begin{array}{c}143,3 \\
2\end{array}$ & 2,20 & $\begin{array}{c}609 \\
4,1 \\
9\end{array}$ & \\
\hline
\end{tabular}

Tabel 4.3 Data Set untuk Training

\begin{tabular}{|c|c|c|c|c|c|c|c|}
\hline $\begin{array}{l}\mathrm{N} \\
\mathrm{o}\end{array}$ & $\begin{array}{l}\text { Tgl } \\
\text { Uji }\end{array}$ & $\begin{array}{l}\text { Hydr } \\
\text { ogen } \\
(\mathrm{H} 2)\end{array}$ & $\begin{array}{l}\text { Metane } \\
(\mathrm{CH} 4)\end{array}$ & $\begin{array}{l}\text { Ethane } \\
\text { (C2H6) }\end{array}$ & $\begin{array}{c}\text { Ethyle } \\
\text { ne } \\
(\mathrm{C} 2 \mathrm{H} 4)\end{array}$ & $\begin{array}{l}\text { TD } \\
\text { CG }\end{array}$ & $\begin{array}{l}\text { Kon } \\
\text { disi }\end{array}$ \\
\hline 1 & $\begin{array}{l}19- \\
\text { Mar } \\
-09\end{array}$ & $\begin{array}{c}243 \\
14\end{array}$ & 14,32 & 18,44 & 0,00 & $\begin{array}{r}275 \\
, 90\end{array}$ & \multirow{3}{*}{ K1 } \\
\hline 2 & $\begin{array}{c}16- \\
\text { Jun- } \\
09\end{array}$ & $\begin{array}{c}647 \\
95\end{array}$ & 27,49 & 23,48 & 1,77 & $\begin{array}{c}702 \\
, 21\end{array}$ & \\
\hline 3 & $\begin{array}{c}3- \\
\text { Mar } \\
-11 \\
\end{array}$ & $\begin{array}{c}448 \\
79\end{array}$ & 36,55 & 29,43 & 45,83 & $\begin{array}{r}564 \\
, 07\end{array}$ & \\
\hline 5 & $\begin{array}{c}22- \\
\text { Dec- } \\
08 \\
\end{array}$ & $\begin{array}{l}145 \\
7,48\end{array}$ & 103,45 & 50,91 & 0,98 & $\begin{array}{c}161 \\
2,8 \\
2 \\
\end{array}$ & \multirow{3}{*}{$\mathrm{K} 2$} \\
\hline 6 & $\begin{array}{c}\text { 6- } \\
\text { Apr- } \\
09\end{array}$ & $\begin{array}{c}689, \\
61\end{array}$ & 38,74 & 46,59 & 0,00 & $\begin{array}{r}825 \\
, 21\end{array}$ & \\
\hline 7 & $\begin{array}{c}13- \\
\text { Oct- } \\
09 \\
\end{array}$ & $\begin{array}{l}153 \\
4,56\end{array}$ & 79,04 & 40,63 & 0,00 & $\begin{array}{c}165 \\
4,2 \\
3 \\
\end{array}$ & \\
\hline
\end{tabular}




\begin{tabular}{|c|c|c|c|c|c|c|c|}
\hline 9 & $\begin{array}{c}30- \\
\text { Jan- } \\
09\end{array}$ & $\begin{array}{l}235 \\
6,65\end{array}$ & 119,52 & & 1,79 & $\begin{array}{c}254 \\
1,3 \\
8\end{array}$ & \multirow{3}{*}{ K3 } \\
\hline 10 & $\begin{array}{c}25- \\
\text { Jan- } \\
10\end{array}$ & $\begin{array}{r}276 \\
9,87\end{array}$ & 117,71 & 84,58 & 1,04 & $\begin{array}{c}297 \\
3,2 \\
0\end{array}$ & \\
\hline 11 & $\begin{array}{c}21- \\
\text { Sep- } \\
10 \\
\end{array}$ & $\begin{array}{l}280 \\
9,77\end{array}$ & 188,66 & $\begin{array}{c}110,5 \\
6\end{array}$ & 1,47 & $\begin{array}{c}311 \\
4,0 \\
6 \\
\end{array}$ & \\
\hline 13 & $\begin{array}{c}15- \\
\text { Jan- } \\
08\end{array}$ & $\begin{array}{l}489 \\
3,09\end{array}$ & 388,44 & $\begin{array}{c}236,5 \\
9\end{array}$ & 0,00 & $\begin{array}{c}551 \\
8,1 \\
2\end{array}$ & \multirow{3}{*}{ K4 } \\
\hline 14 & $\begin{array}{c}26- \\
\text { Feb- } \\
08\end{array}$ & $\begin{array}{c}748 \\
0,23\end{array}$ & 489,55 & $\begin{array}{c}221,7 \\
6\end{array}$ & 11,60 & $\begin{array}{c}802 \\
3,1 \\
4\end{array}$ & \\
\hline 15 & $\begin{array}{c}18- \\
\text { Jun- } \\
08\end{array}$ & $\begin{array}{c}535 \\
0,58\end{array}$ & 510,66 & $\begin{array}{c}444,9 \\
2\end{array}$ & 2,84 & $\begin{array}{c}633 \\
0,2 \\
7\end{array}$ & \\
\hline
\end{tabular}

Perhitungan

\begin{tabular}{|c|c|c|c|c|c|c|c|}
\hline \multicolumn{8}{|c|}{ Tabel 4.4 Data Set untuk Testing } \\
\hline $\begin{array}{l}\mathrm{N} \\
\mathrm{o}\end{array}$ & $\begin{array}{l}\mathrm{Tgl} \\
\mathrm{Uji}\end{array}$ & $\begin{array}{l}\text { Hydr } \\
\text { ogen } \\
(\mathrm{H} 2)\end{array}$ & $\begin{array}{l}\text { Metane } \\
\text { (CH4) }\end{array}$ & $\begin{array}{l}\text { Ethane } \\
\text { (C2H6) }\end{array}$ & $\begin{array}{l}\text { Ethyle } \\
\text { ne } \\
(\mathrm{C} 2 \mathrm{H} 4)\end{array}$ & $\begin{array}{l}\text { TD } \\
\text { CG }\end{array}$ & $\begin{array}{r}\text { Kon } \\
\text { disi }\end{array}$ \\
\hline 4 & $\begin{array}{c}17- \\
\text { Nov } \\
-11\end{array}$ & $\begin{array}{c}137 \\
50\end{array}$ & 120,68 & 49,32 & 0,00 & $\begin{array}{r}307 \\
, 50\end{array}$ & $\mathrm{~K} 1$ \\
\hline 8 & $\begin{array}{c}15- \\
\text { Feb- } \\
10\end{array}$ & $\begin{array}{c}153 \\
7,78\end{array}$ & 96,65 & 67,10 & 1,07 & $\begin{array}{c}170 \\
2,6 \\
0\end{array}$ & K2 \\
\hline 12 & $\begin{array}{c}6- \\
\text { Oct- } \\
11\end{array}$ & $\begin{array}{l}209 \\
2,38\end{array}$ & 84,87 & $\begin{array}{c}111,9 \\
0\end{array}$ & 0,96 & $\begin{array}{c}229 \\
0,1 \\
1\end{array}$ & $\mathrm{~K} 3$ \\
\hline 16 & $\begin{array}{c}1- \\
\text { Feb- } \\
11\end{array}$ & $\begin{array}{l}550 \\
5,06\end{array}$ & 287,91 & $\begin{array}{c}143,3 \\
2\end{array}$ & 2,20 & $\begin{array}{c}609 \\
4,1 \\
9\end{array}$ & K4 \\
\hline
\end{tabular}

Deviasi, Probability, dan Posterior. Sebelum mecari nilai posterior kita terlebih dahulu mencari nilai probabilitas. Untuk mencari probability diperlukan mean dan standart deviasi. Rumus untuk mencari mean, standart deviasi, dan probability.

$\mu=\frac{1}{N} \sum_{i=1}^{N} x i \quad \rightarrow$ Mean

$\sigma^{2}=\frac{1}{(N-1)} \sum_{i=1}^{N}(x i-\mu)^{2} \rightarrow$ Standart Deviasi

$\mathrm{f}(\mathrm{x})=\frac{1}{\sqrt{2 \pi \sigma^{2}}} e^{-\frac{(x-\mu) 2}{2 a}},-\infty<\mathrm{x}<\infty \rightarrow$ Probabilitas

Tapi, disini tidak melakukan perhitungan langsung melainkan menggunakan excel. Setelah didapat nilai probability maka untuk nilai posterior menggunakan rumus:

Posterior

$=\mathrm{P}\left(\mathrm{C}_{\mathrm{K}} \mid \mathrm{H}_{2}, \mathrm{CH}_{4}, \mathrm{C}_{2} \mathrm{H}_{6}, \mathrm{C}_{2} \mathrm{H}_{4}, \mathrm{TDCG}\right)$

$=\mathrm{P}\left(\mathrm{H}_{2} \mid \mathrm{C}_{\mathrm{K}}\right) \cdot \mathrm{P}\left(\mathrm{CH}_{4} \mid \mathrm{C}_{\mathrm{K}}\right) \cdot \mathrm{P}\left(\mathrm{C}_{2} \mathrm{H}_{6} \mid \mathrm{C}_{\mathrm{K}}\right) \cdot \mathrm{P}\left(\mathrm{C}_{2} \mathrm{H}_{4} \mid \mathrm{C}_{\mathrm{K}}\right) \cdot \mathrm{P}\left(\mathrm{TDCG} \mid \mathrm{C}_{\mathrm{K}}\right) \ldots . . . \mathrm{P}(\mathrm{K})$.

Dalam penentuan kelas untuk data set testing kita harus menentukan nilai posterior terbesar pada $\mathrm{K} 1, \mathrm{~K} 2, \mathrm{~K} 3, \mathrm{~K} 4$ untuk setiap no.dataset testing.

Tabel 4.5 Nilai Posterior Data Testing 
- Nomor dataset testing 4, maka dapat ditentukan

\begin{tabular}{|c|c|c|c|c|c|}
\hline N & K1 & K2 & K3 & K4 & KELAS \\
\hline 4 & $\begin{array}{c}0,0007 \\
3343 \\
\end{array}$ & $\begin{array}{c}5,60 \mathrm{E}- \\
06\end{array}$ & $\begin{array}{c}9,09 \mathrm{E}- \\
48 \\
\end{array}$ & $\begin{array}{c}5,32 \mathrm{E}- \\
22 \\
\end{array}$ & K1 \\
\hline 8 & $\begin{array}{c}0,0710 \\
9407\end{array}$ & $\begin{array}{c}9,82 \mathrm{E}- \\
02 \\
\end{array}$ & $\begin{array}{c}2,44 \mathrm{E}- \\
13 \\
\end{array}$ & $\begin{array}{c}9,62 \mathrm{E}- \\
19 \\
\end{array}$ & K2 \\
\hline $\begin{array}{l}1 \\
2\end{array}$ & $\begin{array}{c}0,0707 \\
353 \\
\end{array}$ & $\begin{array}{c}1,30 \mathrm{E}- \\
01\end{array}$ & $\begin{array}{c}6,04 \mathrm{E}- \\
07\end{array}$ & $\begin{array}{c}1,52 \mathrm{E}- \\
17\end{array}$ & K2 \\
\hline $\begin{array}{l}1 \\
6\end{array}$ & $\begin{array}{c}0,0748 \\
2908\end{array}$ & $\begin{array}{c}2,50 \mathrm{E}- \\
01\end{array}$ & $\begin{array}{c}2,43 \mathrm{E}- \\
01\end{array}$ & $\begin{array}{c}4,14 \mathrm{E}- \\
06\end{array}$ & K2 \\
\hline
\end{tabular}
testing 4 adalah $\mathrm{K} 1$.

- Nomor dataset testing 8, karena nilai K2 terbesar maka dapat ditentukan bahwa nomor dataset testing 8 adalah K2.

- Nomor dataset testing 12, karena nilai K2 terbesar maka dapat ditentukan bahwa nomor dataset testing 12 adalah K2.

- Nomor dataset testing 16, karena nilai K2 terbesar maka dapat ditentukan bahwa nomor dataset testing 16 adalah K2.

Hasil Untuk Penentuan Kelas

- Pada nomor dataset testing 4, kelas K1 sama nilainya pada DGA yaitu K1, maka metode naive bayes classifier sesuai dengan metode DGA.

- Pada nomor dataset testing 8, kelas K2 sama nilainya pada DGA yaitu K2, maka metode naive bayes classifier sesuai dengan metode DGA.

- Pada nomor dataset testing 12, kelas K2 tidak sama nilainya pada DGA yaitu K3, maka metode naive bayes classifier tidak sesuai dengan metode DGA.

- Pada nomor dataset testing 16, kelas K2 tidak sama nilainya pada DGA yaitu K4, maka metode naive bayes classifier tidak sesuai dengan metode DGA.

Accuracy didefinisikan sebagai tingkat kedekatan antara nilai prediksi dengan nilai aktual. Ilustrasi berikut ini memberikan gambaran perbedaan antara accuracy dan precision. Secara umum, presisi, recall, akurasi dapat dirumuskan sebagai berikut:

\begin{tabular}{|c|c|c|c|}
\hline & & \multicolumn{2}{|c|}{ Nilai Sebenarnya } \\
\hline & & True & False \\
\hline \multirow{2}{*}{$\begin{array}{l}\text { Nilai } \\
\text { Prediksi }\end{array}$} & True & $\begin{array}{c}\text { TP } \\
\text { (True Positive) }\end{array}$ & $\begin{array}{c}\text { FP } \\
\text { (False Positif) }\end{array}$ \\
\hline & False & $\begin{array}{c}\text { FN } \\
\text { (False Negative) }\end{array}$ & $\begin{array}{c}\mathrm{TN} \\
\text { (True Negative) }\end{array}$ \\
\hline
\end{tabular}

Precision $=\frac{\mathrm{TP}}{\mathrm{TP}+\mathrm{FP}}$

Recall $=\frac{\mathrm{TP}}{\mathrm{TP}+\mathrm{FN}}$

Accuracy $=\frac{\mathrm{TP}+\mathrm{TN}}{\mathrm{TP}+\mathrm{TN}+\mathrm{FP}+\mathrm{FN}}$

Tabel 4.7 Perhitungan Posterior dengan Metode Naive Bayes Classifier

\begin{tabular}{|c|c|c|c|c|c|}
\hline $\begin{array}{l}\mathrm{N} \\
\mathrm{o}\end{array}$ & K1 & K2 & $\mathrm{K} 3$ & K4 & KELAS \\
\hline 4 & $\begin{array}{c}0,00073 \\
343\end{array}$ & $\begin{array}{c}5,60 \mathrm{E}- \\
06\end{array}$ & $\begin{array}{c}9,09 \mathrm{E}- \\
48\end{array}$ & $\begin{array}{c}5,32 \mathrm{E}- \\
22\end{array}$ & K1 \\
\hline 8 & $\begin{array}{c}0,07109 \\
407\end{array}$ & $\begin{array}{c}9,82 \mathrm{E}- \\
02\end{array}$ & $\begin{array}{c}2,44 \mathrm{E}- \\
13\end{array}$ & $\begin{array}{c}9,62 \mathrm{E}- \\
19\end{array}$ & K2 \\
\hline 12 & $\begin{array}{c}0,07073 \\
53\end{array}$ & $\begin{array}{c}1,30 \mathrm{E}- \\
01\end{array}$ & $\begin{array}{c}\text { 6,04E- } \\
07\end{array}$ & $\begin{array}{c}1,52 \mathrm{E}- \\
17\end{array}$ & K2 \\
\hline
\end{tabular}




\begin{tabular}{cccccc}
\hline \multirow{2}{*}{16} & 0,07482 & $2,50 \mathrm{E}-$ & $2,43 \mathrm{E}-$ & $4,14 \mathrm{E}-$ & \multirow{2}{*}{ K2 } \\
& 908 & 01 & 01 & 06 & \\
\hline
\end{tabular}

Tabel 4.8 Perbandingan Perhitungan dan Asli

\begin{tabular}{cc}
\hline PERHITUNGAN & ASLI \\
\hline K1 & K1 \\
\hline K2 2 & K2 \\
\hline K2 32 \\
\hline K2 & K4 \\
\hline
\end{tabular}

Untuk $\mathrm{K} 1 \mathrm{TP}=1, \mathrm{TN}=3, \mathrm{FP}=0, \mathrm{FN}=0$

- Presisi $=\frac{\mathrm{TP}}{\mathrm{TP}+\mathrm{FP}}$

$=1 /(1+0)=1 \times 100 \%=100 \%$

- Recall $=\frac{\mathrm{TP}}{\mathrm{TP}+\mathrm{FN}}$

$=1 /(1+0)=1 \times 100 \%=100 \%$

- Akurasi $=\frac{\mathrm{TP}+\mathrm{TN}}{\mathrm{TP}+\mathrm{TN}+\mathrm{FP}+\mathrm{FN}}$

$=(1+3) /(1+3+0+0)=1 \times 100 \%=100 \%$

Untuk $\mathrm{K} 2 \mathrm{TP}=1, \mathrm{TN}=1, \mathrm{FP}=0, \mathrm{FN}=2$

- Presisi $=\frac{\mathrm{TP}}{\mathrm{TP}+\mathrm{FP}}$

$=1 /(1+0)=1 \times 100 \%=100 \%$

- Recall $=\frac{\mathrm{TP}}{\mathrm{TP}+\mathrm{FN}}$

$=1 /(1+2)=0,3 \times 100 \%=30 \%$

- Akurasi $=\frac{\mathrm{TP}+\mathrm{TN}}{\mathrm{TP}+\mathrm{TN}+\mathrm{FP}+\mathrm{FN}}$

$=(1+1) /(1+1+0+2)=0,5 \times 100 \%=50 \%$

Untuk $\mathrm{K} 3 \mathrm{TP}=0, \mathrm{TN}=3, \mathrm{FP}=1, \mathrm{FN}=0$

- Presisi $=\frac{\mathrm{TP}}{\mathrm{TP}+\mathrm{FP}}$

$=0 /(0+1)=0 \times 100 \%=0 \%$

- Recall $=\frac{\mathrm{TP}}{\mathrm{TP}+\mathrm{FN}}$

$=0 /(0+0)=0 \times 100 \%=0 \%$

- Akurasi $=\frac{\mathrm{TP}+\mathrm{TN}}{\mathrm{TP}+\mathrm{TN}+\mathrm{FP}+\mathrm{FN}}$

$=(0+3) /(0+3+1+0)=0,75 \times 100 \%=75 \%$

Untuk $\mathrm{K} 4 \mathrm{TP}=0, \mathrm{TN}=3, \mathrm{FP}=1, \mathrm{FN}=0$

- Presisi $=\frac{\mathrm{TP}}{\mathrm{TP}+\mathrm{FP}}$

$=0 /(0+1)=0 \times 100 \%=0 \%$

- Recall $=\frac{\mathrm{TP}}{\mathrm{TP}+\mathrm{FN}}$

$=0 /(0+0)=0 \times 100 \%=0 \%$

- Akurasi $=\frac{\mathrm{TP}+\mathrm{TN}}{\mathrm{TP}+\mathrm{TN}+\mathrm{FP}+\mathrm{FN}}$

$=(0+3) /(0+3+1+0)=0,75 \times 100 \%=75 \%$

Setelah diketahui hasil dari perhitungan diatas, lalu membandingkan presisi, recall, akurasi untuk $\mathrm{K} 1, \mathrm{~K} 2, \mathrm{~K} 3$, dan $\mathrm{K} 4$. 


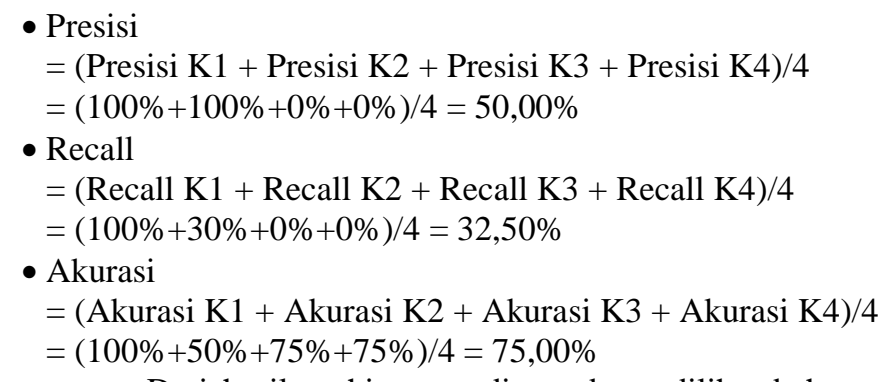

Dari hasil perhitungan diatas dapat dilihat bahwa untuk nilai presisi dan akurasian cukup baik, tetapi untuk nilai recall kurang baik. Salah satu penyebabnya kurangnya data training maupun data testing.

\section{KESIMPULAN}

Berdasarkan data hasil analisis yang telah dilakukan maka dalam pada penyelesaian tugas akhir ini dapat diambil kesimpulan, yaitu:

1. Berdasarkan perhitungan naive bayes classifier pada minyak trafo dengan tingkat kualitasnya $50 \%$ jika dibandingkan metode DGA. Jadi, naive bayes juga dapat digunakan untuk menentukan kualitas minyak trafo.

2. Berdasarkan hasil keadaan minyak isolasi yang diperoleh menggunakan Naive Bayes sesuai dengan keadaan minyak isolasi dengan metode Dissolved Gas Analysis (DGA) yaitu semakin besar data testing untuk input perhitungan naive bayes classifier maka semakin besar pula kondisi minyak trafo berdasarkan nilai posterior kelasnya.

3. Berdasarkan perhitungan presisi dan akurasi cukup baik dengan nilai presisi 50,00\% dan akurasi $75,00 \%$. Sedangkan untuk recall kurang baik yaitu 32,50\%. Jadi, dibutuhkan data hasil uji minyak trafo lebih banyak supaya tingkat presisi, akurasi, recall bisa lebih baik untuk analisis metode Naive Bayes Classifier.

\section{REFERENSI}

[1] Anugroho, P. et al, Klasifikasi Email Spam dengan Meode Naive Bayes Classifier menggunakan Java Programing. Surabaya : Politeknik Elektronika Negeri Surabaya.

[2] Anonym. 2010. Nä̈ve Bayes Classifier. [Online]. Tersedia di: http://en.wikipedia.org/wiki/Naive_Bayes_classifier.

[3] B. Raharjo, "Presisi Dan Akurasi," Beni Raharjo - Nature, Environment, Remote Sensing, GIS, IT and Myself, 17-Mar-2011. [Online]. Available: http://www.raharjo.org/math/presisi-dan-akurasi.html.

[4] Chumaidy Adib, Analisis Kegagalan Minyak Isolasi Pada Transformator Daya Berbasis Kandungan Gas Terlarut.

[5] Hardityo Rahmat. 2008. Tugas Akhir : Deteksi dan Analisis Kegagalan Transformator Dengan Metode Analisis Gas Terlarut. Jakarta : FT UI.

[6] IEEE, "IEEE Guide for the Interpretation of Gases Generated in Oil-Immersed Transformers", IEEE Standard C57-104TM-2008, Sep. 2008.

[7] Marselina - Prediksi Kelulusan dengan Naive Bayes dan C45 - 2010

[8] Sakti Sarjono,Contoh-Perhitungan-Untuk-Naive-Bayes.pdf, 2010

[9] Wibisono, Y. 2005. Klasifikasi Berita Berbahasa Indonesia menggunakan Nä̈ve Bayes Classifier. [Online]. Tersedia http://fpmipa.upi.edu/staff/yudi/yudi0805.pdf.

[10] Wikipedia: Bayesian spam filtering. http://en.wikipedia.org/wiki/Bayesian_spam_filtering. 
ELKOM “Jurnal Teknik Elektro Dan Komputasi"

Vol. 1, No. 1, Agustus 2019, Hal: 36-45

ISSN: , DOI: , Terakreditasi Dikti dengan SK:

\section{BIOGRAFI PENULIS}

Sofia Ariyani adalah dosen di lingkungan Program Studi Teknik Elektro Universitas
Muhammadiyah Jember. Topik penelitiannya berkaitan dengan pengembangan system
elektronika dan system telekomunikasi. age $\mid 45$

